\title{
Angraecum inflatum, a new species in Angraecinae (Orchidaceae) from Madagascar
}

\author{
Johan Hermans $^{1,2}$ (D), Landy Rajaovelona ${ }^{3} \&$ Phillip Cribb ${ }^{1}$
}

Summary. A new species from Madagascar, Angraecum inflatum Hermans, is described and illustrated for the first time. It is compared with similar species from section Lemurangis. A preliminary conservation assessment is provided.

Key Words. IUCN Red List assessments, section Lemurangis, taxonomy.

\section{Introduction}

Angraecum Bory (subfamily Epidendroideae: tribe Vandeae: subtribe Angraecinae) (Chase et al. 2015) is a large genus of over 200 species occurring mainly in Africa, Madagascar and adjacent islands of the Indian Ocean but it is notably speciose on Madagascar with 148 species, two subspecies, and four varieties. Just over $10 \%$ of these taxa also occur in the Mascarenes and the Comoros (Hermans in Goodman 2021, in press). Following the major work on the Madagascan angraecoid orchids by Schlechter $(1915,1925)$ and Perrier de la Bâthie (1938, 1941), Garay (1973) produced a taxonomic revision of the genus at sectional level. Several investigations of the phylogeny and biogeography of the genus have recently been made (Michenau et al. 2008; Szlachetko et al. 2013; Andriananjamanantsoa et al. 2016; Simo-Droissart et al. 2018) which suggest that Angraecum, as currently accepted, is polyphyletic. However, because these studies have sampled only a limited selection of species, we do not feel confident in accepting those segregates that have been established based on molecular data and lack morphological support.

\section{Materials and Methods}

As part of ongoing research and fieldwork on the orchid flora of Madagascar at the Royal Botanic Gardens Kew, the University of Vienna and PBZT Antananarivo, specimens of putative new taxa were compared with descriptions, herbarium material and drawings of all of the type specimens and many other specimens, to ascertain their novelty. This has resulted in the recognition of a new species in section Lemurangis, a section first established by Garay (1973:
501), for a small group of plants of eight species, predominantly endemic to Madagascar.

The conservation status of the new species given in this paper is a summary of the full IUCN Red List assessments which will be completed and submitted for review and publication by IUCN once the species name is validly published. The assessment has been compiled based on current knowledge of the taxon, by one of the authors (Landy Rajaovelona), who is an IUCN Red List assessor, using the IUCN Red List Categories and Criteria (2012).

Angraecum inflatum Hermans sp. nov. Type: Madagascar, Fianarantsoa prov., Ankazomivady area, c. 1500 m, cult. Malala Orchidées, 1999, Hermans 4935 (holotype $\mathrm{K} !)$.

http://www.ipni.org/urn:lsid:ipni.org:names:77218372-1

Pendent to arching, tufted epiphytic herb up to $18 \mathrm{~cm}$ long, loosely attached to the substrate and forming large overlapping colonies along the mossy substrate; with an extensive mass of branched, wiry, smooth to slightly verrucose basal roots, c. $1 \mathrm{~mm}$ in diam. Stem branching from the base and rarely re-branching, up to $17 \mathrm{~cm}$ long, $4-6 \mathrm{~mm}$ wide, more or less flattened, completely covered by winged leaf sheaths with erose to lacerate, recurved apical margins, the base and withered stems covered by grey corrugate leaf sheath remnants. Leaves succulent, alternate-distichous along the stem, twisted at the base to almost lie in one plane, elliptic to narrowly ovate, $15-19 \times 5-7 \mathrm{~mm}$, elliptic in cross-section, with a canaliculate mid-vein, round underneath, obtuse to rounded at the base, unequally

\footnotetext{
Accepted for publication 19 April 2021. Published online 24 August 2021

1 Herbarium, Royal Botanic Gardens, Kew, Richmond, Surrey, TW9 3AE, UK. e-mail: j.hermans@kew.org

2 Core Facility, Botanical Garden, University of Vienna, Rennweg 14, 1030 Vienna, Austria.

3 Kew Madagascar Conservation Centre, Lot II J 131 Ambodivoanjo, Ivandry, Madagascar.
} 


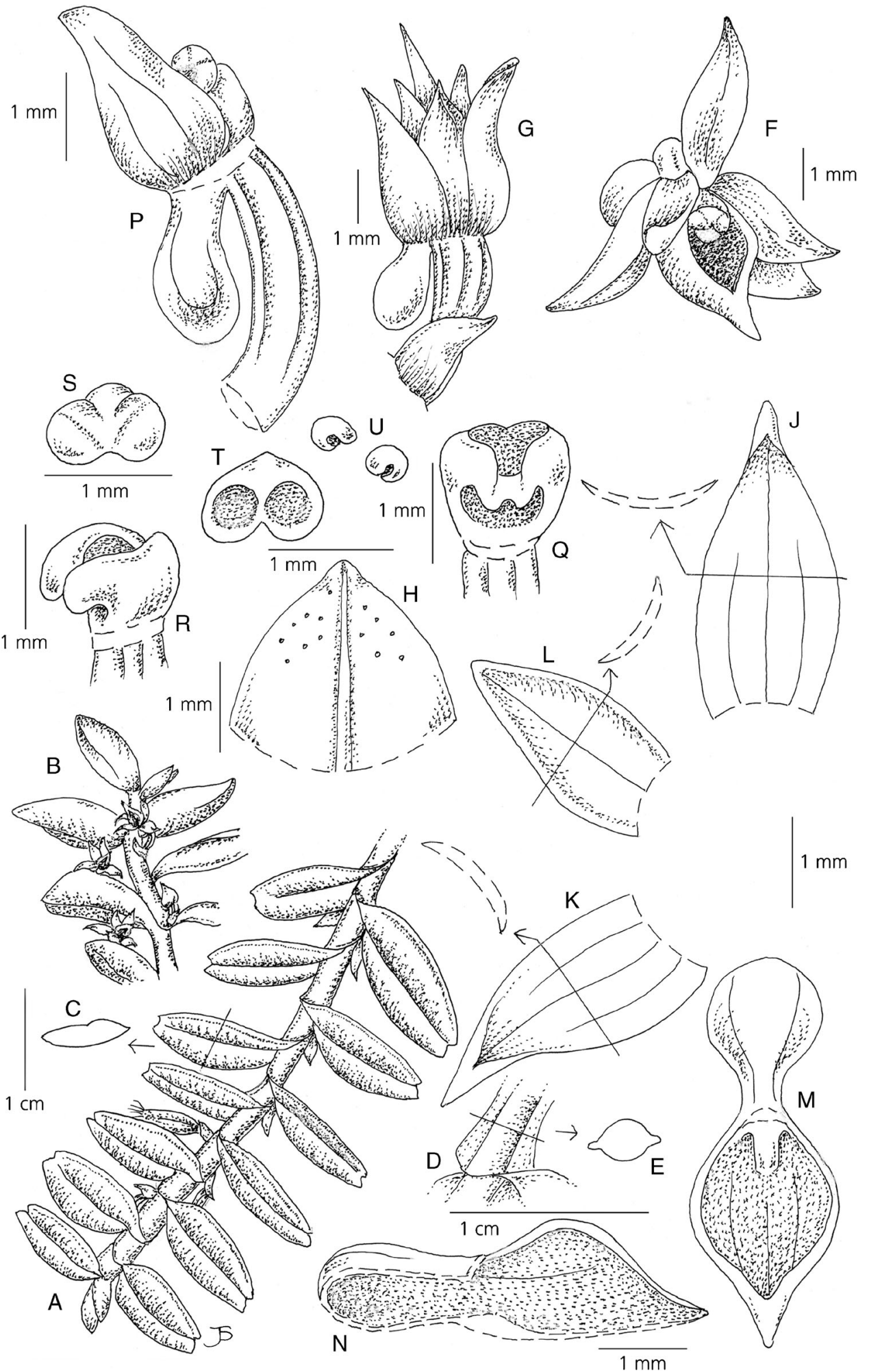

Fig. 1. Angraecum inflatum. A plant habit; B detail of plant and inflorescences; C transverse section of leaf; D detail of stem; $\mathrm{E}$ transverse section of stem; $\mathrm{F}$ flower front view; $\mathrm{G}$ flower side view; $\mathrm{H}$ floral bract; J dorsal sepal; $\mathrm{K}$ lateral sepal; $\mathrm{L}$ petal; $\mathrm{M}$ lip from above; $\mathbf{N}$ lateral section of lip; $\mathbf{P}$ column and lip, side view; Q column, front view, anther cap removed; $\mathrm{R}$ column, side view, anther cap removed; S anther cap, dorsal view; T anther cap, ventral view; U pollinia. From Hermans 8296, 4935 \& photographs. DRAWN BY JUDI STONE. 

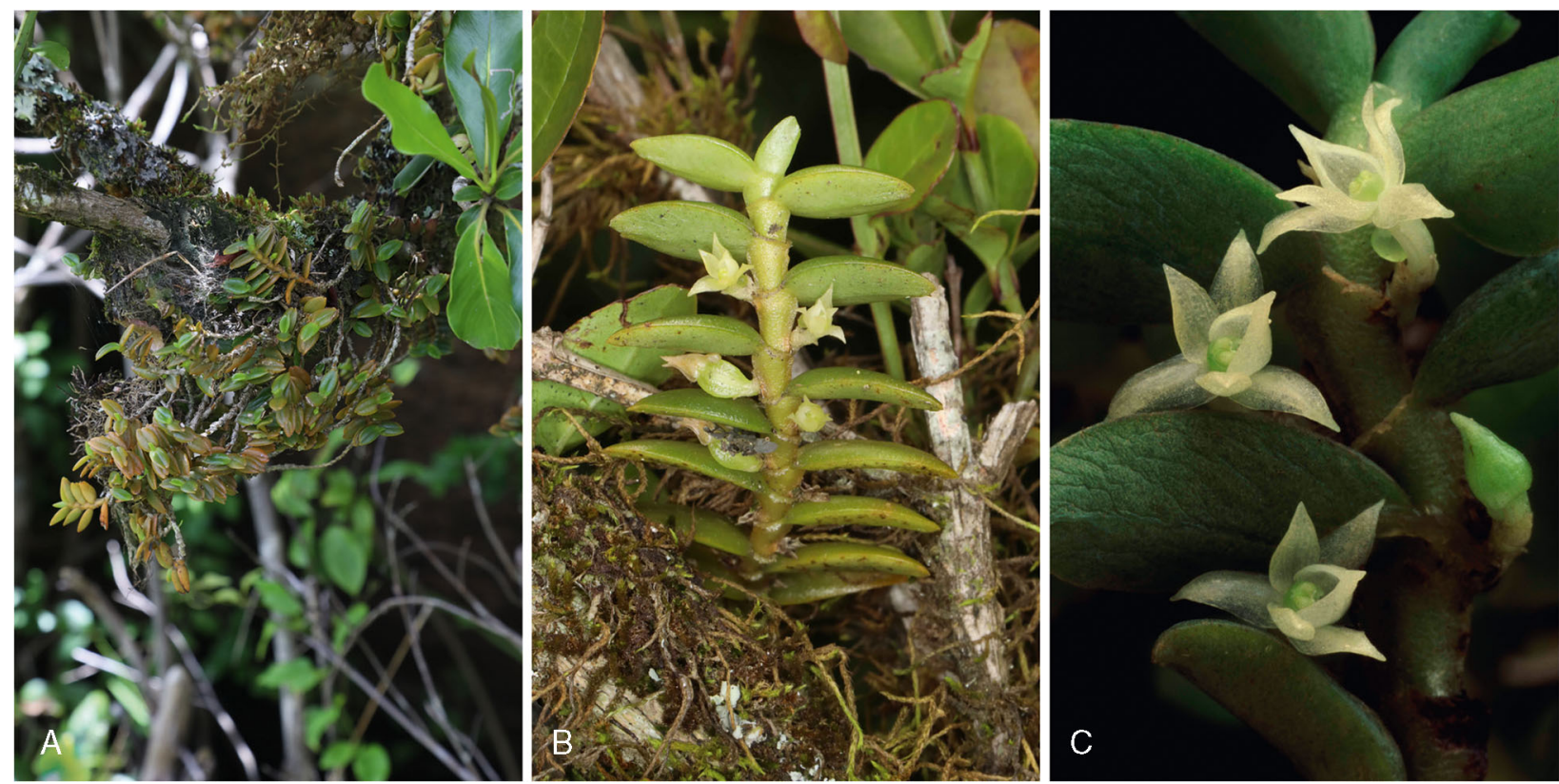

Fig. 2. Angraecum inflatum. A plant habit, from the Ankazomivady area, Madagascar; B plant growth and inflorescence; $\mathbf{C}$ flowers and developing capsules. PHOTOS: J. HERMANS.

roundly bilobed at the apex, pale to dark green, sometimes becoming orange-brown with age. Inflorescence from the axis of the leaf sheaths, very short, generally single-flowered, leaf-opposed; sometimes with a second flower from the same axis. Peduncle very short, angular in cross-section, c. $0.3-0.5 \times 0.2 \mathrm{~mm}$, covered by 1 - 3 thin sterile bracts. Floral bracts thin, ovate, conduplicate, dorsally ridged, apiculate, $1.8-2.1 \times 1.2$ $-1.5 \mathrm{~mm}$, pale brown. Pedicel and ovary fusiform, $2-3.2 \times$ $0.7-0.9 \mathrm{~mm}$, with a few brownish black verrucae along the longitudinal furrows. Flowers generally resupinate, overall $6-7 \times 5-7 \mathrm{~mm}$ diam., pale greenish-yellow, the spur, column and ovary pale green. Dorsal sepal ovate, 2.8 $-3.8 \times 1.5-1.8 \mathrm{~mm}$, acuminate, thickened at the apex, recurved in the apical half. Lateral sepals, ovate, acuminate, thickened at the apex, $3.2-4 \times 1.2-1.7 \mathrm{~mm}$, spreading, recurved. Petals ovate, acuminate, $2.3-3.4 \times$ $0.9-1.3 \mathrm{~mm}$. Lip deeply concave, elliptic, acuminate, the apical margin thickened-incurved, with a short longitudinal callus at the base, $2.5-3.2 \times 1.5-1.8 \mathrm{~mm}$, spur opening narrow, cylindrical at the base then ampulliform, more or less flattened against the substrate, $1.6-2.3 \times 1-1.2 \mathrm{~mm}$. Column very short, rounded, with distinct dolabriform lateral rostellum lobes folded in front of the distal part, apex of rostellum deeply emarginate with a small rounded central lobe, c. $1 \times 1$ $\mathrm{mm}$, stigma transversely elliptic. Anther cap transversely elliptic in outline, with a raised rounded lobe, $0.4-0.7 \times$ $0.5-0.8 \mathrm{~mm}$; pollinia 2, obovoid, c. $0.2 \times 0.3 \mathrm{~mm}$, indistinct stipes and a small viscidium c. $0.1 \mathrm{~mm}$ long. Fruit c. $6 \times 4 \mathrm{~mm}$, subglobose to ovoid, roundly ridged, maturing as other flowers develop. (Figs 1, 2).
RECOGNITION. Angraecum inflatum fits well in sect. Lemurangis Garay which is characterised by the long stem, distichous leaves, few-flowered inflorescences shorter than the leaves and short rachis. It is distinct in having short fleshy ovoid leaves, winged stem sheaths with an erose-lacerate apical margin, inflorescences with a very short peduncle, and flowers with a lip with thickened margins, a small longitudinal callus at the base and an ampulliform spur and the capsule maturing as other flowers develop.

DISTRIBUTION. MADAGASCAR. Endemic to Fianarantsoa province in central Madagascar.

SPECIMENS EXAMINED. MADAGASCAR. Madagascar, Fianarantsoa prov., Ankazomivady area, c. 1500 m, 1999, Hermans 4935 (K - type) cult. Malala Orchidées, 2014; Hermans 7024 E 8296 (K); Antoetra, Feb. 2015, A. E C. Sieder, Pertl E A Andriantiana 6883 (WU); sight records Ankazomivady, Hermans Jan. 2019.

HABITAT. Sclerophyllous woodland and forest remnants, on Ficus and other small trees. Altitude 1200 $1700 \mathrm{~m}$.

CONSERVATION STATUS. Angraecum inflatum is endemic to Madagascar, restricted to the Amoron'i Mania region (Fianarantsoa province). The type locality is now being cleared for charcoal and the cultivation of Pelargonium, grown increasingly in the region to produce essential oils. The two collections with the recent observations represent a total of two 'locations' (sensu IUCN 2012) with respect to the main threat, which is shifting agriculture. With the observations and the two collections outside the protected areas, we infer that the destruction of the habitat will induce a 
strong continuous decline in the area of occupancy (AOO), habitat extent and quality, the number of subpopulations and mature individuals in the next ten years. Angraecum inflatum is therefore assessed as Endangered (EN) under criterion B2ab (i, ii, iii, iv, v). PHENOLOGY. December to February.

ETYMOLOGY. The epithet name refers to swollen leaves, lip margin and puffed-up spur.

NOTES. Angraecum inflatum is most similar to A. baronii (Finet) Schltr. from Madagascar but in that species the stem is more extensively branched, the leaves are narrowly lanceolate (vs ovate) and the apex attenuate (vs rounded); the peduncle is about twice as long; and the flowers are similar in size but the lip is more acuminate and thin towards the apex and the spur is cylindrical and curved at the apex (vs ampulliform). It is also similar to A. costatum Frapp. in Cordem. from Réunion but in that species the plant is more erect with slightly longer and less succulent leaves; the flowers are a little larger and the spur about twice as long; the lip lacks a basal callus and the spur is slightly swollen towards the apex (vs ampulliform).

The circumscription of section Lemurangis needs further research as part of a revision of all the sections of Angraecum but the key below summarises the differential characteristics of the currently recognised species.

\section{Artificial key to the species of Angraecum sect. Lemurangis}

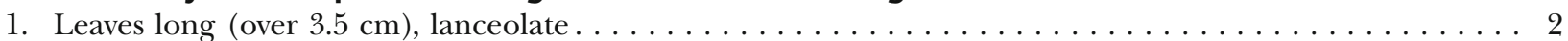

1'. Leaves short (under $3 \mathrm{~cm}$ ), ovate or falciform $\ldots \ldots \ldots \ldots \ldots \ldots$

2. Leaves over $8 \mathrm{~cm}$ long, attenuate at the base, flowers over $2 \mathrm{~cm}$ long

$\ldots \ldots \ldots \ldots \ldots \ldots \ldots \ldots \ldots \ldots \ldots \ldots \ldots \ldots \ldots \ldots \ldots \ldots$ Angraecum floribundum Bosser (Madagascar)

2'. Leaves under $6 \mathrm{~cm}$ long, obtuse at the base, flowers under $1.5 \mathrm{~cm}$ long . . Angraecum costatum (Réunion)

3. Leaves falciform, narrow (more than 5 times longer than wide) $\ldots \ldots \ldots \ldots$

3'. Leaves broad (less than 3 times longer than wide) $\ldots \ldots \ldots \ldots \ldots \ldots$

4. Lip over $4 \mathrm{~mm}$ long, spur over $2.5 \mathrm{~mm}$ long. . . . . . . . . . . . Angraecum falcifolium Bosser (Madagascar)

4'. Lip under $3.5 \mathrm{~mm}$ long, spur under $2 \mathrm{~mm}$ long . . . . . . . Angraecum decaryanum H.Perrier (Madagascar)

5. Plant small (under $3 \mathrm{~cm}$ ) on a short stem . . . . . . . . . Angraecum humile Summerh. (E Africa)

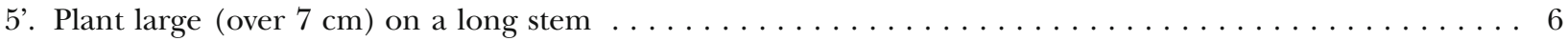

6. Leaves distichous, distant, base rounded, not enveloping the stem, single-flowered, spur strongly inflated at

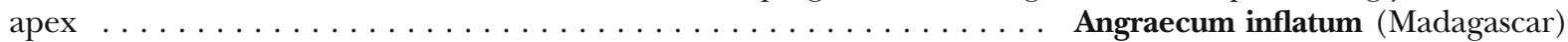

6'. Leaves contiguous, base enveloping the stem, 2- to 4-flowered, spur not much inflated . . . . . . . . 7

7. Inflorescence as long as the leaves or longer, floral bracts half the length of the ovary. . . . . . . . . . $\ldots \ldots \ldots \ldots \ldots \ldots \ldots \ldots \ldots$ Angraecum alleizettei Schltr. (Madagascar \& Réunion)

7'. Inflorescence half the length of the leaves or shorter, floral bracts about as long as the ovary ............. $\ldots \ldots \ldots \ldots \ldots \ldots \ldots \ldots \ldots \ldots \ldots \ldots \ldots \ldots \ldots \ldots \ldots$ Angraecum madagascariense (Finet) Schltr. (Madagascar)

\section{Acknowledgements}

We are most grateful to the directors and staff at BM, BR, BRLU, CBNM, DBN, E, G, HEID, K, L, M, MAU, MO, P, SZU, TAN, TEF, W, WU, M, SZL and ZSS for making their collections available.

Open Access This article is licensed under a Creative Commons Attribution 4.0 International License, which permits use, sharing, adaptation, distribution and reproduction in any medium or format, as long as you give appropriate credit to the original author(s) and the source, provide a link to the Creative Commons licence, and indicate if changes were made. The images or other third party material in this article are included in the article's Creative Commons licence, unless indicated otherwise in a credit line to the material. If material is not included in the article's Creative Commons licence and your intended use is not permitted by statutory regulation or exceeds the permitted use, you will need to obtain permission directly from the copyright holder. To view a copy of this licence, visit http://creativecommons.org/ licenses/by/4.0/.

\section{References}

Andriananjamanantsoa, H., Engberg, S., Louis, E. \& Brouillet, L. (2016). Diversification of Angraecum (Orchidaceae, Vandeae) in Madagascar: Revised phylogeny reveals species accumulation through time rather than rapid radiation. PLOS ONE 11: e 0163194 .doi:https://doi.org/10.1371/ journal.pone.0163194.

Chase, M. W., Cameron, K. M., Freudenstein, J. V., Pridgeon, A. M., Salazar, C., Van den Berg, C. \& Schuiteman, A. (2015). An updated classification of Orchidaceae. J. Linn. Soc., Bot. 177: 151 - 174. 
Garay, L. A. (1973). Systematics of the genus Angraecum (Orchidaceae). Kew Bull. 28: 495 - 516.

Hermans, J. (2021, in press). Orchidaceae - an overview. In: S. M. Goodman (ed.), The new natural history of Madagascar. Princeton University Press, Princeton.

IUCN (2012). IUCN Red List categories and criteria, Version 3.1. prepared by the IUCN Species Survival Commission. IUCN, Gland and Cambridge.

Micheneau, C., Carlsward, B. S., Fay, M. F., Bytebier, B., Pailler, T. \& Chase, M. (2008). Phylogenetics and biogeography of Mascarene angraecoid orchids (Vandeae, Orchidaceae). Molec. Phylogenet. Evol. 46: 908 - 922.

Perrier de la Bâthie, H. (1938). Sarcanthae nouvelles ou peu connues de Madagascar (fin). Notul. Syst. (Paris) 7: $105-139$.

(1941). In: H. Humbert, Flore de Madagascar. 49 e. Famille. - Orchidées. Tananarive Imprimerie Officielle, Madagascar.

Schlechter, R. (1915). Kritische Aufzählung der bisher von Madagaskar, den Maskarenen, Komoren und Seychellen bekanntgewordenen Orchidaceen. Beih. Bot. Centralbl. 33: $390-440$.
(1925). Orchidaceae Perrieranae. Repert. Spec. Nov. Regni Veg. Beih. 33: 241 - 391.

Simo-Droissart, M., Plunkett G. M, Droissart, V., Edwards, M. B., Farminhão, J. N. M., Ječmenica, V., D'Haijère, T., Lowry, P.P. II, Sonké, B., Micheneau, C., Carlsward, B. S., Azandi, L., Verlynde, S., Hardy, O. J., Martos, F., Bytebier, B., Fischer, E. \& Stévart, T. (2018). New phylogenetic insights toward developing a natural generic classification of African angraecoid orchids (Vandeae, Orchidaceae). Molec. Phylogenet. Evol. 126: 241 - 249.

Szlachetko, D. L., Tukallo, P., Mytnik-Ejsmont, J. \& Grochocka, E. (2013). Reclassification of the Angraecum-alliance (Orchidaceae, Vandoidae) based on molecular and morphological data. Biodivers. Res. Conservation. 29: 1 - 23.

\section{Publisher's Note}

Springer Nature remains neutral with regard to jurisdictional claims in published maps and institutional affiliations. 